\title{
Corrigendum: "Two new species of Echinoderes (Kinorhyncha: Cyclorhagida) from the Gulf of Mexico"
}

\author{
Martin V. Sørensen ${ }^{1 *}$ and Stephen C. Landers ${ }^{2}$ \\ ${ }^{1}$ Natural History Museum of Denmark, University of Copenhagen, Copenhagen, Denmark, ${ }^{2}$ Department of Biological and \\ Environmental Sciences, Troy University, Troy, AL, USA
}

Keywords: Kinorhyncha, Taxonomy, Cyclorhagida, Echinoderes, Gulf of Mexico

\section{OPEN ACCESS}

Edited by:

Tito Monteiro Da Cruz Lotufo,

University of São Paulo, Brazil

Reviewed by:

Fernando Pardos,

Universidad Complutense de Madrid,

Spain

Maikon Di Domenico,

University of Campinas, Brazil

*Correspondence:

Martin V. Sørensen,

mvsorensen@snm.ku.dk

Specialty section:

This article was submitted to Marine Systematics and Taxonomy,

a section of the journal

Frontiers in Marine Science

Received: 26 May 2015 Accepted: 28 May 2015

Published: 10 June 2015

Citation:

Sørensen MV and Landers SC (2015)

Corrigendum: "Two new species of

Echinoderes (Kinorhyncha:

Cyclorhagida) from the Gulf of

Mexico". Front. Mar. Sci. 2:43.

doi: 10.3389/fmars.2015.00043

\section{A corrigendum on}

Two new species of Echinoderes (Kinorhyncha: Cyclorhagida) from the Gulf of Mexico by Sørensen, M. V., and Landers, S. C. (2014). Front. Mar. Sci. 1:8. doi: 10.3389/fmars.2014.00008

Sørensen and Landers (2014) recently described the two kinorhynch species Echinoderes augustae and E. skipperae. In order to ensure validity of the two new species, and to follow the rules of the ICZN regarding new species described in electronic publications, the species were subsequently registered in Zoobank (www.zoobank.org), and the publication (Sørensen and Landers, 2014) was added to Zoobank under LSID number urn:lsid:zoobank.org:pub:054F74AE-74F5-4D9F-8E02373A55471760.

\section{Acknowledgments}

This research was made possible by a grant from BP/The Gulf of Mexico Research Initiative.

\section{References}

Sørensen, M. V., and Landers, S. C. (2014). Two new species of Echinoderes (Kinorhyncha: Cyclorhagida) from the Gulf of Mexico. Front. Mar. Sci. 1:8. doi: 10.3389/fmars.2014.00008

Conflict of Interest Statement: The authors declare that the research was conducted in the absence of any commercial or financial relationships that could be construed as a potential conflict of interest.

Copyright ( 12015 Sørensen and Landers. This is an open-access article distributed under the terms of the Creative Commons Attribution License (CC BY). The use, distribution or reproduction in other forums is permitted, provided the original author(s) or licensor are credited and that the original publication in this journal is cited, in accordance with accepted academic practice. No use, distribution or reproduction is permitted which does not comply with these terms. 